\title{
ANAL YSIS OF THE FACTORS AFFECTING THE CONSUMER PURCHASING DECISIONS ON COFFEE AT RESTO BANARAN 9, GEMAWANG VILLAGE, SEMARANG
}

\author{
Asnita Lase ${ }^{1)}$ Agus Setiadi ${ }^{1)}$ Kustopo Budiraharjo ${ }^{1)}$ \\ 1) Program of Agribisnis, the Faculty of Animal Husbandry and Agriculture, the University of Diponegoro. Email: \\ agus_setiadi2006@yahoo.co.id. Email: kustopo.65@gmail.com, Email: asnita.lase.al@ gmail.com
}

\begin{abstract}
This study aims to determine the general description of Resto Banaran 9, to analyze general description of coffee consumers in Resto Banaran 9 which includes respondent characteristics, consumption behavior, and respondent's answer distribution, in additionto analyze the influence of cultural factors, social factors, personal factors, psychological factors, and physical evidence on coffee purchasing decisions at Resto Banaran 9. This research was conducted on 10 September until 11 October 2018 at Resto Banaran 9, Gemawang Village, Jambu Sub-district, Semarang District. The location of the research was determined purposively. This research method was a survey and data collection techniques through interviews using a questionnaire tool distributed to 100 respondents. The sampling method used was the accidental sampling method. Data analysis used was descriptive-quantitative analysis method. The quantitative analysis used was multiple linear regression analysis. The results showed that simultaneously, cultural factors, social factors, personal factors, psychological factors, and physical evidence had a significant effect on consumers' coffee purchasing decisions at Resto Banaran 9. Moreover, partially, cultural factors, social factors, personal factors, psychological factors, and physical evidence had a significant effect on consumers' coffee purchasing decisions at Resto Banaran 9.
\end{abstract}

Keywords: Purchasing Decision, Coffee, and Resto Banaran 9.

\section{PRELIMINARY}

Coffee is a type of beverage that is often consumed by the public. The tradition of drinking coffee in the morning is very typical in the community. However, recently, not only is coffee drunken in the morning, but also at lunch or afternoon breaks. The tradition of drinking coffee nowadays is very beneficial to relieve tiredness and thirst as well as refreshment in relaxation. As this tradition leads to an upward trend in the number of coffee drinkers, it has taken a part of the lifestyle.

Recent changes in the lifestyle of the Indonesian people are caused by the development of science and technology which then influences people's consumption patterns making them need more values rather than just eating and drinking. Consequently, their consumption trends have turned to pleasure oriented.

Changes in lifestyle and increasing demand for coffee provoked the emergence of various brands and coffee shops in various regions including Semarang. Resto Banaran 9, for example, is one of the restaurants that provides coffee menus and is seen as a place that can reflect a person's lifestyle.

According to Suryani (2008), two factors influence consumer purchasing decisions. The first factor is the behaviour of the people in the circumstances who can influence decisions about what to buy. The second one is unexpected situational 
factors, in which consumers may intent to buy something based on unexpected factors that can change consumer purchase intentions.

Besides, according to Kotler and Keller (2012) factors that influence consumer purchasing decisions are cultural factors, social factors, personal factors, and psychological factors. Hurriyati (2010) added that physical evidence also influences consumer purchasing decisions in using various products offered. Based on these opinions, the variables that the researchers used in this study were cultural factors, social factors, personal factors, psychological factors, and physical evidence. Lifestyle changes along with increasing demand for coffee at Resto Banaran 9 are the main reasons why the authors are interested in conducting research entitled "Analysis of Factors Affecting Consumers Purchasing Decisions on Coffee at Banaran 9 Resto, Gemawang Village, Jambu Sub-District, Semarang Regency".

The purpose of this study was to find out the general description of Banaran 9 Resto, analyse the general description of coffee consumers at Resto Banaran 9 which includes respondent characteristics and consumer behaviour, as well as analysing the factors that influence consumer purchasing decisions on coffee at Resto Banaran 9.

\section{RESEARCH METHODS}

The research was conducted from September 10 to October 11, 2018, at Resto Banaran 9 Village Gemawang, Jambu District, Semarang Regency. The research location was determined by the purposive sampling technique with the consideration that Resto Banaran 9 is a restaurant whose buildings are specially designed so that the atmosphere of coffee drinking brings a fresh and comfortable atmosphere and can reflect the lifestyle of today society.

The method used in this research was the survey method. Surveys are research methods that take samples from one population and use questionnaires as a tool to collect data (Sugiyono, 2015).
The sampling method used was accidental sampling. The accidental sampling method is a coincidence sampling method that is a consumer who accidentally or incidentally meets with a researcher at the time of the research is selected as an informant (Sugiyono, 2015). Respondents in this study were consumers who were met while drinking coffee at Resto Banaran 9 and fulfilled the predetermined requirements, namely consumers ages are $\geq 23$ years because it was assumed that at that age respondents had been actively earning financial and respondents who had drunk coffee at Resto Banaran 9 at least twice. The sample determined in this study consisted of 100 respondents. Determination of the number of samples in this study refers to the theory of Widiyanto (2008) which states that in determining the research sample if the population is large and the number is unknown, the formula used is:

$$
\mathrm{n}=\frac{\mathrm{Z}^{2}}{4(\mathrm{moe})^{2}} \mathrm{n}=\rightarrow \frac{1,96^{2}}{4(0,1)^{2}} \rightarrow \mathrm{n}=96,04
$$

With:

$\mathrm{N}=$ Sample Size

$\mathrm{Z}=$ Accuracy Degree 95\% (with

$\alpha=0.5$, it is 1.96 )

Moe $=$ Margin of error $(10 \%)$, the highest acceptable error value.

Based on this calculation, the number of samples used in this study was rounded up to 100 respondents.

Data Collection Method. The primary data collection method used in this study was the interview method using a questionnaire tool. The secondary data collection method used in this study was the method of observation and literature. Observation is a technique of collecting data with systematic observation and recording. The literature study is data collection carried out by comparing data obtained with existing literature (Sugiyono, 2015).

Data Types and Sources. The type of data used in this study is primary data and secondary data. The former type of data is data that specifically collected and 
processed directly used for research. The primary data source was obtained through interviews with coffee consumers at Resto Banaran 9 by referring to the questionnaire given to respondents. Secondary data is data that has been processed by other parties as supporting writing (Sugiyono, 2015). Secondary data taken in this study was a general description of the company and other required data. Secondary data in this study were obtained from Resto Banaran 9, journals, previous research, and related books.

Data Analysis Method. The data analysis method used in this study was the descriptive-quantitative analysis method. Descriptive analysis is a statistical method used to analyse data by describing or illustrating collected data (Sugiyono, 2015). The descriptive analysis aims to provide a description or illustration systematically, factually, and accurately based on the existed facts in addition to investigating the properties or relationships among the phenomena (Ghozali, 2012). Quantitative data analysis is based on numbers and calculations using statistical methods using the SPSS program (Sugiyono, 2015). The quantitative analysis used was the multiple linear regression analysis.

Data obtained from the field were processed and measured using the scoring method. The statement in the questionnaire for each variable was measured using a Likert scale with a scale of 1-5. Likert scale is a scale used to measure attitudes, opinions, perceptions of a person or group of people about existing social phenomena (Sugiyono, 2015).

The calculation results from the score or value were then used in statistical analysis using the SPSS 16.0 program through data testing as follows:

Instrument Feasibility Test. A validity test is used to measure the extent of the accuracy of a measuring instrument in performing its measuring function (Matondang, 2009). The minimum standard measuring instrument is said to be valid if the Pearson Correlation value is $\geq 0.3$ or the value of the Sig. (2- tailed) Is $\leq 0.05$ (Darmawan, 2013). Besides, a reliability test is used to determine the extent to which a measuring device can be trusted which is proven from the extent to which the measurement results remain consistent after being done for twice or more by the same measuring instrument (Nisfiannoor, 2009). The data is said to be reliable if the value of Cronbach's Alpha is above 0.6 (Sugiyono, 2015).

\section{Normality Test and Classical Assumption}

Test. A normality test is used to determine whether the data are normally distributed or not (Sugiyono, 2015). If the value of Asymp. Sig. (2-tailed) Is one variable greater than the significant level of 5\% (> 0.050 ), and then the variable is normally distributed (Apriyono and Taman, 2013). Besides, a multicollinearity test is a test used to determine whether there is a correlation between independent variables in the regression model used (Denziana et al., 2014). Regression is free from multicollinearity if the VIF value is $<10$ and the Tolerance value is $>0.10$ (Haslinda and Jamaluddin, 2016). The autocorrelation test was used to find out whether there was a correlation between confounding errors in period $\mathrm{t}$ and interfering errors in the period $\mathrm{t}-1$ (Nisfiannoor, 2009). There is no autocorrelation if the inequality of the values is $\mathrm{dU}<\mathrm{dW}<4-\mathrm{dU}$ (Ghozali, 2012).

A heteroscedasticity test is done to find out whether in regression there is a variance from residual inequality, one observation to another observation (Haslinda and Jamaluddin, 2016). A regression model is said to be good if there are no specific patterns on the graph, such as assembling in the middle, but then narrowing then widening or otherwise widening then narrowing and the points spread above and below the number 0 on the $\mathrm{y}$-axis (Sutopo and Slamet, 2017).

Analysis of Multiple Linear Regression. A regression analysis is used to find out whether the independent variable influences the dependent variable (Ghozali, 2012). The multiple linear regression equation is as follows: 
$\mathbf{Y}=\mathbf{a}+\mathrm{b}_{1} \mathbf{X}_{1}+\mathbf{b}_{2} \mathbf{X}_{2}+\mathbf{b}_{3} X_{3}+\mathbf{b}_{4} X_{4}+b_{5} X_{5}+\varepsilon$

Note:

$\mathrm{Y}=$ Consumer Decisions

$\mathrm{a} \quad=$ Constant Coefficient

$b_{1}, b_{2}, b_{3}, b_{4}, b_{5}=$ Regression Coefficient of Each Variable

$\mathrm{X}_{1} \quad=$ Culture Factor

$\mathrm{X}_{2} \quad=$ Social Factor

$\mathrm{X}_{3} \quad=$ Individual Factor

$\mathrm{X}_{4} \quad=$ Psychology Factor

$\mathrm{X}_{5} \quad=$ Physical Evidence

$\varepsilon=$ Error, disturbing variable

(Sugiyono, 2015).

Hypothesis testing. Hypothesis testing consists of a simultaneous test ( $F$ test), partial test (t-test) and coefficient of determination (R2). The $\mathrm{F}$ test aims to determine whether all the independent variables jointly influence the dependent variable (Santoso, 2012). Independent variables have a simultaneous effect on the dependent variable if the value of Fcount> Ftable or Sig. $<0.05$ (Suharyadi and Purwanto, 2011).

The test is used to find out how far the influence of an independent variable partially in explaining the variation of the dependent variable (Kurniawan and Yuniarto, 2016). The independent variable partially influences the dependent variable if $\mathrm{t}$ count $>\mathrm{t}$ table or Sig. $<0.05$ (Suharyadi and Purwanto, 2011). The coefficient of determination is used to measure how far the model's ability to explain variations in the dependent variable (Ghozali, 2012). R2 values range from 0 to 1 ; the value of $\mathrm{R} 2$ which is getting closer to 1 indicates the influence of independent variables on the dependent variable is getting stronger (Nawari, 2010).

Table 1. Characteristics of Respondents

\begin{tabular}{|c|c|c|}
\hline Characteristic & Number (People) & Percentage $(\%)$ \\
\hline \multicolumn{3}{|l|}{ 1. Gender } \\
\hline Male & 65 & 65 \\
\hline Female & 35 & 35 \\
\hline \multicolumn{3}{|l|}{ 2. Age } \\
\hline $23-30$ & 32 & 32 \\
\hline $31-38$ & 43 & 43 \\
\hline $39-46$ & 18 & 18 \\
\hline$>46$ & 7 & 7 \\
\hline \multicolumn{3}{|l|}{ 3. Education } \\
\hline Primary School & 5 & 5 \\
\hline Junior High School & 17 & 17 \\
\hline Senior High School & 14 & 14 \\
\hline Undergraduate/Diploma & 64 & 64 \\
\hline \multicolumn{3}{|l|}{ 4. Occupation } \\
\hline Civil Servant & 38 & 38 \\
\hline Private Employee & 19 & 29 \\
\hline Entrepreneur & 30 & 30 \\
\hline Miscellaneous & 13 & 13 \\
\hline \multicolumn{3}{|l|}{ 5. Income } \\
\hline $1,000,000-3,000,000$ & 10 & 10 \\
\hline$>3,000,000-5.000 .000$ & 26 & 26 \\
\hline$>5,000,000-7,000,000$ & 28 & 28 \\
\hline$>7,000,000$ & 36 & 36 \\
\hline
\end{tabular}

Source: Processed Primary Data, 2018. 
Table 2. Consumption Behavior.

\begin{tabular}{|c|c|c|}
\hline $\begin{array}{l}\text { Consumption } \\
\text { Behavior }\end{array}$ & $\begin{array}{l}\text { Number } \\
\text { (People) }\end{array}$ & $\begin{array}{l}\text { Percentage } \\
(\%)\end{array}$ \\
\hline \multicolumn{3}{|c|}{$\begin{array}{l}\text { 1. Purchasing } \\
\text { Time }\end{array}$} \\
\hline $\begin{array}{l}\text { Time } \\
\text { Morning }\end{array}$ & 20 & 20 \\
\hline Noon & 54 & 54 \\
\hline Afternoon & 14 & 14 \\
\hline Night & 12 & 12 \\
\hline \multicolumn{3}{|c|}{$\begin{array}{l}\text { 2. Purchasing } \\
\text { Frequency }\end{array}$} \\
\hline $2-3$ & 17 & 17 \\
\hline $4-5$ & 19 & 19 \\
\hline $6-7$ & & 34 \\
\hline$>7$ & & 30 \\
\hline
\end{tabular}

Source: Processed Primary Data, 2018.

\section{RESULTS AND DISCUSSION}

General Description of Resto Banaran 9. Resto Banaran 9 is located next to Banaran Coffee Factory, a factory that processes coffee from coffee beans into the ground coffee. It is the main attraction of the Gemawang Banaran 9 Resto because consumers can enjoy coffee while seeing the coffee processing at the same time. Besides, the location of Banaran 9 Resto is very strategic as it is placed on the Magelang-Semarang Big Street. This resto is well known by people travelling to Semarang, Yogyakarta, Cilacap, and other cities due to the fact that this place is often used as a place to rest and relax for a moment while travelling.

Characteristics of Respondents. The description of the characteristics of the respondents is as follows:

The number of female respondents is less than that of the male. It can occur because the level of preference of most men toward coffee is generally higher than that of women. These results are consistent with the research of Tarigan et al. (2015) which states that men consume coffee more often than women because it is related to other habits such as smoking, gathering, and staying up late.
Respondents who were included in the age range of 31-38 years had the most number in this study. This is because the interval of 31-38 years is a productive age for work. According to Weinberg and Bealer (2010) caffeine contained in coffee works in the body by inhibiting the absorption of adenosine to relieve drowsiness and inhibit fatigue. This opinion was supported by Bawazeer and Alsobahi (2013) who stated that coffee is consumed to provide stimulation, increase energy, and relieve drowsiness. Many respondents drink coffee to get rid of sleepiness while working.

Respondents with an undergraduate /diploma education level had the most significant number in this study. According to Yulianti and Deliana (2018) consumers with better levels of education will be very responsive to the information and knowledge gained in making purchasing decisions. This opinion was supported by Rukhbaniyah et al. (2013) which states that higher levels of education make a person think more critically, thus making them think before making a purchasing decision.

Respondents who work as civil servants have the most number in this study. Respondents with other not-mentioned jobs are respondents who work as temporary employees, architects, chefs, farmers, and drivers. The number of respondents who work as civil servants washuge as this is one of the efforts to increase family income. Mulyadi (2012) says the size of income used for the level of family welfare is household income obtained from work.

Respondents, who have an income of more than $\operatorname{Rp} 7,000,000$, have the largest proportion of this study. Based on the description it can be concluded that a large portion of the income of respondents who drank coffee at Banaran 9 Resto was higher than Semarang's Minimum Wage (UMK) of Rp 2,310,087, - based on the Central Java Governor's Decree Number 560/94 the Year 2017. Education Agency and Financial Training of the Ministry of Finance (Ministry of Finance Ministry of Finance) (2015) classifies the class of income per 
month in Indonesia into three classes, namely the middle class with income between Rp. 2,600,000, - up to Rp. 6,000,000 per month, lower middle class with income of less than Rp. 2,600,000 per month and the upper middle class with income of more than Rp. 6,000,000 per month.

Consumption Behavior. The respondent consumption behaviour is shown in Table 2 . Respondents who drank coffee at Resto Banaran 9 during the day had the most considerable portion of this study. According to Sudiyarto et al. (2012), coffee shops are usually crowded during the day because many students usually visit a coffee shop after studying at school and workers tend to spend their break time in coffee shops while chatting or conducting business talks. Khamdani (2014) added that coffee shops are also a useful place for conducting many kinds of communication forms, such as dialogue, discussion, interview, research observation, discussion, and so forth.

Respondents who drank coffee at Resto Banaran 9 as many as 6-7 times in one month had the highest percentage in this study. Based on these figures it can be concluded that respondents often drink coffee at Resto Banaran 9. Charina (2016) stated that the reason someone consumes coffee that is to get a sense of comfort and relaxation after consuming coffee, increase stamina and physical performance, improve memory and concentration, and obtain health benefits. According to Ukur (2017), many consumers visit the coffee shop because the coffee shop is not only used as a place to drink coffee but is an alternative public space that has various functions such as being a place for family gatherings, business meetings, social, cultural events, and so on.

\begin{abstract}
Analysis of Factors Affecting Purchasing Decisions. The factors that influence coffee consumer purchasing decisions are analysed using multiple linear regression analysis.
\end{abstract}

Test the feasibility of the instrument. The feasibility test of the instrument consists of:
Data Validity Test. The test of the validity of the data is shown in Table 3.

Based on the results of the validity test of all question items it has the Pearson correlation value of $>0.3$ and the Sig. (2tailed) Obtained in all question items calculated to 0,000 so that it was $<0.05$. Accordingly, it can be concluded that all items in question were valid and therefore could be used for research.

Data Reliability Test. The data reliability test results are listed in Table 4.

The reliability test results show that the Cronbach's Alpha value on each variable was greater than 0.6 so that it can be said that all measuring concepts of each variable from the questionnaire was reliable.

\section{Normality Test and Classical Assumption}

Test. The normality test and classic assumption test are described as follows:

Data Normality Test. The results of the data normality test as shown in Table 5.

The results of the normality test indicated that the value of Asymp. Sig. (2-tailed) each variable was greater than 0.05 so that it can be concluded that all data used in this study were usually distributed.

Multicollinearity Test. The results of the multicollinearity test as shown in Table 6 .

The results of multicollinearity test show that all tolerance values were $>0.1$ and VIF values were $<10$. Based on these results, it can be concluded that there was no multicollinearity between independent variables in the regression model.

Autocorrelation Test. Based on the results of the autocorrelation test that has been carried out, the Durbin-Watson value was 2.124. The autocorrelation test used 100 respondents, and five independent variables have a dL value of 1.5710 and a dU value of 1.7804. Based on the Durbin-Watson value obtained it can be seen that $\mathrm{dU}<\mathrm{dW}$ $<4-\mathrm{dU}$ or $1.7804<2.124<2.2196$, so it can be concluded that there is no autocorrelation in the data. 
Table 3. Data Validity Test Results.

\begin{tabular}{|c|c|c|c|}
\hline No. & Variable & Question Number & Pearson Correlation \\
\hline \multirow[t]{5}{*}{1.} & Culture Factor (X1) & X1.1 & 0.801 \\
\hline & & $\mathrm{X} 1.2$ & 0.808 \\
\hline & & $\mathrm{X} 1.3$ & 0.782 \\
\hline & & $\mathrm{X} 1.4$ & 0.835 \\
\hline & & $\mathrm{X} 1.5$ & 0.682 \\
\hline \multirow[t]{5}{*}{2.} & Social Factor (X2) & $\mathrm{X} 2.1$ & 0.778 \\
\hline & & $\mathrm{X} 2.2$ & 0.816 \\
\hline & & $\mathrm{X} 2.3$ & 0.589 \\
\hline & & $\mathrm{X} 2.4$ & 0.506 \\
\hline & & $\mathrm{X} 2.5$ & 0.688 \\
\hline \multirow[t]{5}{*}{3.} & Individual Factor (X3) & X3.1 & 0.766 \\
\hline & & X3.2 & 0.848 \\
\hline & & X3.3 & 0.541 \\
\hline & & X3.4 & 0.746 \\
\hline & & X3.5 & 0.782 \\
\hline \multirow[t]{5}{*}{4.} & Psychology Factor (X4) & $\mathrm{X} 4.1$ & 0.856 \\
\hline & & $\mathrm{X} 4.2$ & 0.862 \\
\hline & & $\mathrm{X} 4.3$ & 0.723 \\
\hline & & $\mathrm{X} 4.4$ & 0.861 \\
\hline & & $\mathrm{X} 4.5$ & 0.818 \\
\hline \multirow[t]{5}{*}{5.} & Physic Factor (X5) & X5.1 & 0.688 \\
\hline & & $\times 5.2$ & 0.908 \\
\hline & & $\mathrm{X} 5.3$ & 0.814 \\
\hline & & X5.4 & 0.910 \\
\hline & & $\mathrm{X} 5.5$ & 0.815 \\
\hline \multirow[t]{5}{*}{6.} & Purchasing Decision & Y.1 & 0.839 \\
\hline & & Y.2 & 0.836 \\
\hline & & Y.3 & 0.613 \\
\hline & & Y.4 & 0.848 \\
\hline & & Y.5 & 0.742 \\
\hline
\end{tabular}

Source: Processed Primary Data, 2018.

Table 4. Data Reliability Test Results.

\begin{tabular}{lc}
\hline Variable & Cronbach's Alpha \\
\hline Culture Factor (X1) & 0.837 \\
Social Factor (X2) & 0.661 \\
Individual Factor (X3) & 0.780 \\
Psychology Factor (X4) & 0.881 \\
Physic Evidence (X5) & 0.881 \\
Purchasing Decisions (Y) & 0.833 \\
\hline
\end{tabular}

Source: Processed Primary Data, 2018

Table 5. Data Normality Test Results.

\begin{tabular}{lc}
\hline Variable & Asymp. Sig. (2-tailed) \\
\hline Culture Factor (X1) & 0.061 \\
Social Factor (X2) & 0.079 \\
Individual Factor (X3) & 0.054 \\
Psychology Factor (X4) & 0.057 \\
Physic Evidence (X5) & 0.057 \\
Purchasing Decisions (Y) & 0.063 \\
\hline
\end{tabular}

Source: Processed Primary Data, 2018 
Table 6. Multicollinearity Test Results

\begin{tabular}{lll}
\hline Variable & Tolerance & VIF \\
\hline Culture Factor (X1) & 0.320 & 3.122 \\
Social Factor (X2) & 0.155 & 6.448 \\
Individual Factor (X3) & 0.132 & 7.591 \\
Psychology Factor (X4) & 0.174 & 5.732 \\
Physic Evidence (X5) & 0.244 & 4.095 \\
\hline
\end{tabular}

Source: Primary Data Processed, 2018.

Heteroscedasticity Test. The results of the heteroscedasticity test as shown in Illustration 1 are as follows:

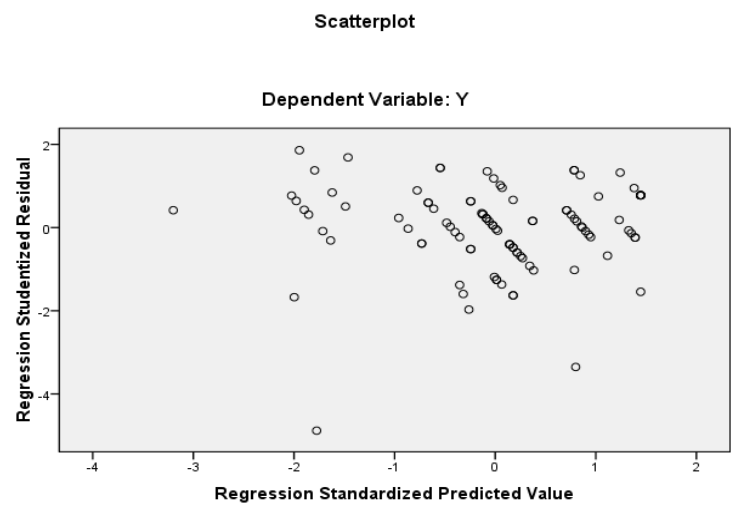

The results of the heteroscedasticity test shown in Illustration 1 show that the points did not form a particular pattern or there were no clear patterns and the points spread above and below the number 0 (zero) on the y-axis so that it can be concluded that heteroscedasticity did not occur.

Multiple Linear Regression. According to Ghozali (2012), multiple linear regression analysis is used to determine the effect of independent variables on the dependent variable. The regression equation obtained was:

$\mathrm{Y}=0.071+0.126 \mathrm{X}_{1}+0.229 \mathrm{X}_{2}+0.215 \mathrm{X}_{3}+$ $0.252 X_{4}+0.148 X_{5}+\varepsilon$

The regression equation is explained as follows:

1. Constant (a) of 0.071 , meaning that if cultural factors, social factors, personal factors, psychological factors, and physical evidence were zero, then the consumer purchasing decision for coffee at Banaran 9 Resto was 0.071.

2. The regression coefficient of cultural factor variable (X1) of 0.126 shows that if the cultural factor variable increases by one value, then the consumer purchasing decision will increase by 0.126 assuming the other independent variables have a fixed value.

3. The regression coefficient of the social factor variable (X2) of 0.229 indicates that if the social factor variable increases by one value, then the consumer purchasing decision will increase by 0.229 assuming the other independent variables have a fixed value.

4. The regression coefficient of the personal factor variable (X3) of 0.215 shows that if the personal factor variable increases by one value, then the consumer purchasing decision will increase by 0.215 assuming the other independent variables have a fixed value.

5. The regression coefficient of the psychological factor variable (X4) of 0.252 indicates that if the psychological factor variable increases by one value, then the consumer purchasing decision will increase by 0.252 assuming the other independent variables are of fixed value.

6. The regression coefficient of physical evidence variable (X5) of 0.148 shows that if the physical evidence variable increases by one value, then the consumer purchasing decision will increase by 0.148 assuming the other independent variables are of fixed value.

Hypothesis testing, Hypothesis testing consists of:

F Test (Simultaneous Test). Based on the results of the $F$ test that has been done, it is known that the value of Fcount was 136.266 and the significance value as 0.000 . Based on the values listed in table $\mathrm{F}$, it is known that the Ftable value was 2.31. The calculated $F$ value was more significant than Ftable where 136,266> 2,31 and the Sig value. Obtained for 0,000 where 0,000 $<0,05$ so it can be concluded that $\mathrm{H} 0$ 
cultural factor variables, social factors, personal factors, psychological factors, and physical evidence together (simultaneously) had a significant effect on consumer purchasing decisions.

T-test (Partial Test). The t-test results listed in Table 7.

Based on the results of the t-test that has been done, it is known that the count and significance values of each variable were different. The table is 1.985 .

he t-test results of cultural factors were 2.108 with a significance value of 0.038 , tcount $>$ table where 2.108> 1.985 and significance values were smaller than 0.05 where $0.038<0.05$, so $\mathrm{H} 0$ was rejected, and $\mathrm{H} 1$ was accepted which means significant cultural factors towards consumer purchasing decisions. $\mathrm{H} 1$ also means that the higher the cultural factor, the higher consumer purchasing decisions will be. The results of this study are consistent with the research conducted by Nawawi (2017) which showed that cultural factors partially influence consumer purchasing decisions in consuming Single Origin coffee.

The results of the t-test on social factor variables are 2.622 with a significance value of 0.010 , tcount $>t$ table where 2.622> 1.985 and significance values were smaller than 0.05 where $0.010<0.05$, so $\mathrm{H} 0$ rejected and $\mathrm{H} 1$ accepted, which means that social factors have a significant effect on consumer purchasing decisions. $\mathrm{H} 1$ also means that the higher social factors, consumer purchasing decisions will increase. The results of this study are under the research of Pangestu and Suryoko (2016) which show that social classes have a partial effect on peacockoffie consumer purchasing decisions in Semarang.

The results of the t-test on personal factor variables are 2.177 with a significance value of 0.032 , tcount $>\mathrm{t}$ table where $2.177>1.985$ and significance values were smaller than 0.05 where $0.032<0.05$, so $\mathrm{H} 0$ rejected and $\mathrm{H} 1$ accepted, which means that personal factors have a significant effect on consumer purchasing decisions. H1 also means that the higher the personal factor, the higher the consumer purchasing decision will be. The results of this study are in accordance with the research of Marbun et al. (2014) which shows that personal factor variables partially have a significant effect on the purchasing decisions of Sidikalang coffee civet coffee.

The results of the t-test on psychological factor variables are 3.050 with a significance value of 0.003 , tcount $>t$ table where 3,050>1,985 and significance values were smaller than 0.05 where 0.003 $<0.05$, so H0 rejected and $\mathrm{H} 1$ accepted which means that psychological factors had a significant effect on consumer purchasing decisions. H1 also means that the higher psychological factors, consumer purchasing decisions will increase. The results of this study are by the research conducted by Marbun et al. (2014) which showed that psychological variables partially have a significant effect on consumer decisions of civet coffee.

The results of t-test on physical evidence variables were 2.153 with a significance value of 0.034 , tcount $>t$ table where 2.153> 1.985 and significance values smaller than 0.05 where $0.034<0.05$, so $\mathrm{H} 0$ rejected and $\mathrm{H} 1$ accepted, which means that physical evidence has a significant effect on consumer purchasing decisions. H1 also means that the higher the physical evidence, the higher consumer purchasing decision will be. The results of this study are consistent with the research of Wiyaya and Siswanto (2013) which shows that physical evidence has a partial effect on consumer purchasing decisions in Comedy Kopi Surabaya Town Square (SUTOS).

Table 7. Test Results t

\begin{tabular}{lll}
\hline Variable & T & Sig. \\
\hline Culture Factor (X1) & 2.108 & 0.038 \\
Social Factor (X2) & 2.622 & 0.010 \\
Individual Factor (X3) & 2.177 & 0.032 \\
Psychology Factor (X4) & 3.050 & 0.003 \\
Physic Evidence (X5) & 2.153 & 0.034 \\
\hline
\end{tabular}

Source: Processed Primary Data, 2018. 
Determination Coefficient Test (R2). Based on the results of the coefficient of determination (R2) analysis, it is known that the Adjusted R Square value was 0.872, meaning that cultural factors, social factors, personal factors, psychological factors, and physical evidence can explain the purchasing decision variable of $87.2 \%$ and the rest $12.8 \%$ was explained by other notmentioned variables in this study. Based on these results, it can be concluded that

\section{CONCLUSIONS AND RECOMMENDATIONS}

\section{Conclusion}

Based on the results of data analysis and discussion that have been described, it can be concluded that:

1. For the characteristics of respondents in Resto Banaran 9, respondents were dominated by male, age group of 31-38 years old, Bachelor/Diploma education background, civil servants, monthly income of > Rp. 7,000,000. The consumption behaviour of respondents at Banaran 9 Resto was the usual drinking coffee at Resto Banaran 9 during the day and the frequency of buying coffee as many as 6-7 times in 1 month.

2. Simultaneously cultural factors, social factors, personal factors, psychological factors, and physical evidence had a significant effect on coffee purchasing decisions at Resto Banaran 9. Partially cultural factors, social factors, personal factors, psychological factors, and physical evidence variables significantly influence decisions purchase of coffee at Resto Banaran 9.

\section{Recommendation}

1. Companies or producersare expected to pay more attention to consumer characteristics and lifestyles related to consumer purchasing decisions so that companies or producers can understand consumers and can create effective and efficient marketing strategies.

2. The next researcher can develop this research by analysing other factors that can influence consumer purchasing decisions so that they can provide other advice to the company in order to increase the rate of consumer purchasing.

\section{REFERENCES}

Apriyono, A. dan A. Taman. 2013. Analisis overreaction pada saham perusahaan manufaktur di Bursa Efek Indonesia (BEI) periode 2005-2009. J. Nomina. 2(2): 76-96.

Badan Pendidikan dan Pelatihan Keuangan Kementrian Keuangan. 2015. Penghasilan Kelas Menengah Naik = Potensi Pajak. (http://www.bppk.kemenkeu.go.id /publikasi/artikel/167artikelpajak/21014-penghasilan-kelas-menengah-naik-potensi-pajak). Tanggal diakses 15 Oktober 2018.

Bawazeer, N. A. dan Alsobahi, N. A. 2013. Prevalence and side effects of energy drink consumption among medical students at Umm Al-Qura University Saudi Arabia. J. Medical Students. 1(3): 8-104.

Charina, D. 2016. Faktor-faktor yang mempengaruhi keputusan pembelian minuman kopi di Malabar Mountain Cafe Kota Bogor. Fakultas Ekonomi dan Manajemen Institut Pertanian Bogor. Bogor. (Skripsi).

Darmawan, D. 2013. Metode Penelitian Kuantitatif. PT Remaja Rosdakarya.

Denziana, A., Indrayenti dan F. Fatah. 2014. Corporate financial performance effects of macro economic factors against stock return. J. Akuntansi dan Keuangan. 5(2): 17-40. 
Ghozali, I. 2012. Aplikasi Analisis Multivariate dengan Program SPSS. Badan Penerbit Universitas Diponegoro, Semarang.

Haslinda dan Jamaluddin, M. 2016. Pengaruh perencanaan anggaran dan evaluasi anggaran terhadap kinerja organisasi dengan standar biaya sebagai variabel moderating pada pemerintah daerah Kabupaten Wajo. J. Ilmiah Akuntansi Peradaban. 2(1): 1-21.

Hurriyati, R. 2010. Bauran Pemasaran dan Loyalitas Konsumen. Alfabeta, Bandung.

Khamdani, D. F. 2014. Tema sosial yang didialogkan oleh komunitas "ngopi" di warung kopi Sarijan Malang. J. Pendidikan Kewarganegaraan. 1(1): 1770-1780.

Kotler, P. dan Armstrong, G. 2012. Prinsip-Prinsip Pemasaran. Erlangga, Jakarta.

Kurniawan, R. dan B. Yuniarto. 2016. Analisis Regresi Dasar dan Penerapannya dengan R. Kencana, Jakarta.

Marbun, I. I., R. Ginting dan Emalisa. 2014. Analisis faktor-faktor yang mempengaruhi perilaku konsumen Kopi Luwak bermerek di Kota Medan. Social Economic of Agriculture and Agribusiness Journal.3(6): 1-14.

Matondang, Z. 2009. Validitas dan reliabilitas suatu instrumen penelitian. J. Tabularasa. 6(1): 8797.

Mulyadi, S. 2012. Ekonomi Sumber Daya Manusia dalam Perpektif Pembangunan. PT Raja Grafindo Persada, Jakarta.

Nawari. 2010. Analisis Regresi dengan MS Excel 2007 dan SPSS 17. PT Elex Media Komputindo, Jakarta.

Nawawi, A. 2017. Faktor-faktor yang mendorong konsumen mengkonsumsi kopi Single Origin (Studi pada Komunitas Penikmat Kopi (KPK) Lampung di kedai kopi Coffee Paste). Fakultas Ilmu Sosial dan Ilmu Politik Universitas Lampung, Lampung. (Skripsi).

Nisfiannoor, M. 2009. Pendekatan Statistika Modern untuk Ilmu Sosial. Salemba Humanika, Jakarta.

Pangestu, S. D. dan S. Suryoko. 2016. Pengaruh gaya hidup (lifestyle) dan harga terhadap keputusan pembelian (Studi kasus pada pelanggan Peacockoffie Semarang). J. Administrasi Bisnis. 5(1): 1-12.

Rukhbaniyah, L. Y., D. P. Utami dan I. A. Wicaksono. 2013. Perilaku konsumen terhadap kopi tubruk dan kopi instan di Kecamatan Pejagoan Kabupaten Kebumen. J. Ilmu Pertanian dan Peternakan. 2(1): 31-40.

Santoso, S. 2012. Panduan Lengkap SPSS Versi 20. PT Elex Media Komputindo, Jakarta.

Sudiyarto, S. Widayanti dan D. M. Kresna. 2012. Perilaku konsumen penikmat kopi tubruk dan kopi instan. Social and Agricultural Economics Journal. 6(3): 1-11.

Sugiyono. 2015. Metode Penelitian Pendidikan Pendekatan Kuantitatif, Kualitatif dan R\&D. Alfabeta, Bandung.

Suharyadi dan Purwanto. 2011. Statistika untuk Ekonomi dan Keuangan Modern. Salemba Empat, Jakarta. 
Suryani, T. 2008. Perilaku Konsumen: Implikasi Pada Strategi Pemasaran. Graha Ilmu, Yogyakarta.

Sutopo, Y. dan A. Slamet. 2017. Statistik Inferensial. Andi, Yogyakarta.

Tarigan, E., D. Pranowo dan T. Iflah. 2015. Tingkat kesukaan konsumen terhadap kopi campuran robusta dengan arabika. J. Teknologi dan Industri Pertanian Indonesia. 7(1): 12-17.

Ukur, D. D. N. 2017. Pengaruh store atmoesfer dan harga terhadap loyalitas pelanggan coffee shop di Bandung (Kopi Om). Fakultas Manahemen Universotas Widyatama, Bandung. (Tesis).

Weinberg, B. A. dan B. K. Bealer. 2010. The Miracle of Caffeine: Manfaat Tak Terduga Kafein Berdasarkan Penelitian Paling Mutakhir. Diterjemahkan oleh Warastutu. Qanita, Bandung.

Widiyanto, I. 2008. Pointers: Metodologi Penelitian. Badan Penerbit Universitas Diponegoro, Semarang.

Wijaya, A. V. dan C. Siswanto. 2013. Analisis pengaruh people, physical evidence dan product terhadap keputusan pembelian konsumen di Comedy Kopi Surabaya Town Square (SUTOS). J. Hospitality dan Manajemen Jasa. 1(1): 1-13.

Yulianti, Y. dan Y. Deliana. 2018. Gaya hidup kaitannya dengan keputusan konsumen dalam membeli minuman kopi. J. Agrisep. 17(1): 39-50. 